\title{
SITUS LIANGAN DALAM BINGKAI SEJARAH MATARĀM KUNO
}

\section{POSITIONING OF THE LIANGAN SITE IN THE OLD MATARĀM HISTORICAL FRAMEWORK}

\author{
Sugeng Riyanto \\ Balai Arkeologi Daerah Istimewa Yogyakarta \\ sugeng66riyanto@gmail.com
}

\begin{abstract}
Liangan site - found in 2008 and being researched since 2009 - is an intricate site. At least three type of areas have been unearthed, viz. settlement, agriculture, and Hinduistic worship, which buried in 3 hectares area of Mt. Sindoro volcanic material. Archaeological data and carbon dating have indicated that Liangan site extend between II to XI AD. Thus, the specific historical context of Liangan based on existing archaeological evidences has become a separate issue. Through descriptive-analytical methods, supported by historical sources, it is known that the ancient civilization of Liangan had developed sincepre-Hindu to Ancient Matarām periods. To be more specific, the Liangan site can be associated with Rakai Layang Dyah Tlodhong, the king of Matarām who reigned from 918 to 928 AD, both indicating that the ancient Liangan settlements were of watak, not wanua.
\end{abstract}

Keyword : Liangan site, Ancient Matarām, pre-Hindu, ancient settlement.

\begin{abstract}
ABSTRAK
Situs Liangan yang ditemukan tahun 2008 dan diteliti sejak tahun 2009 merupakan situs yang tergolong kompleks. Setidaknya ada tiga area yang sudah diketahui yaitu hunian, pertanian, dan pemujaan berlatar Hindu. Hingga 2016, situs yang terkubur oleh material vulkanis Gunung Sindoro ini sudah terbuka sekitar 3 hektare. Berdasarkan identifikasi data arkeologi dan pengumuran melalui analisis karbon, secara kronologis situs Liangan ditempatkan setidaknya dari abad II hingga XI Masehi. Hal itu selanjutnya menjadi permasalahan tersendiri, yaitu konteks kesejarahan situs Liangan secara spesifik berdasarkan bukti-bukti data arkeologis. Berkaitan dengan hal itu, dengan metode deskriptif-analitis yang didukung sumber-sumber sejarah, diketahui bahwa Liangan kuno berkembang sejak pra-Hindu hingga masa kejayaan Matarām Kuno. Lebih spesifik lagi, situs Liangan dapat dikaitkan dengan Rakai Layang Dyah Tlodhong, raja yang memerintah Matarām dari tahun $918 \mathrm{M}$ sampai $928 \mathrm{M}$, sekaligus menunjukkan bahwa permukiman Liangan kuno adalah setingkat watak, bukan wanua.
\end{abstract}

Kata Kunci : Situs Liangan, Matarām Kuno, pra-Hindu, Permukiman kuno.

\footnotetext{
Tanggal Masuk : : 30 Mei 2017

Tanggal Diterima : : 15 Agustus 2017
} 


\section{PENDAHULUAN}

\begin{tabular}{lrr}
\multicolumn{1}{c}{ Situs } & Liangan & di Dusun \\
Liangan, & Desa & Purbosari, \\
Kecamatan Ngadirejo, & Kabupaten \\
Temanggung, Jawa & Tengah,
\end{tabular} merupakan salah satu situs yang tergolong baru, jika dihitung dari ditemukannya data arkeologi pada akhir 2008 secara tidak sengaja oleh para penambang pasir. Penelitian 2009 merupakan kegiatan survei pendahuluan yang kemudian menjadi acuan dalam penyusunan rencana strategis dan dituangkan menjadi program penelitian bertahap yang terbagi menjadi dua jenjang, yaitu jangka menengah I (2010 2014) dan jangka menengah II (2015 - 2019) (Riyanto, 2014a: 5-6, 2325). Situs Liangan terdiri atas area atau lokasi-lokasi yang terkait dengan aktivitas pemujaan, aktivitas hunian, dan aktvitas pertanian yang ketiganya integral. Peradaban Liangan kuno secara kronologis sedikitnya berada pada rentang abad II-XI, bahkan sebelum masuknya anasir budaya India, hingga masa kejayaan Matarām Kuno. Situs Liangan terkubur oleh material vulkanis Gunung Sindoro (Riyanto, 2016: 50) yang letaknya hanya sekitar 8 kilometer dari puncak.

Gambaran itu menjadikan Liangan disebut sebagai situs yang sangat kompleks, selain areanya yang juga luas. Kompleksitas situs Liangan juga diperlihatkan oleh keragaman data yang hampir semuanya dalam kondisi hangus karena terdampak oleh erupsi Gunung Sindoro. Data tersebut meliputi 1) struktur dan bangunan terdiri atas candi, batur, pagar, talud, dan jalan batu 2) fitur yang terdiri atas lubang-lubang bekas tiang bambu maupun kayu serta fitur lahan pertanian, 3) artefak berbahan keramik Tiongkok masa Dinasti
Tang berbagai bentuk; artefak wadah berbahan tembikar; artefak batu seperti manik-manik, pipisan, dan gandik; serta artefak berbahan logam berbagai bentuk, 4) data organik, dalam hal ini merupakan data yang tergolong langka, yaitu kain berbentuk lembaran dan kantong bertali; bahan pengan dan hasil pertanian seperti gabah, pala, dan biji-bijian; fragmen kayu dari unsur bangunan maupun pohon, 5) ekofak yang umumnya meliputi fragmen tulang fauna (Riyanto, 2015: 36-46). Keragaman data itu menunjukkan bahwa Liangan bukan sekadar situs pemujaan tetapi cenderung sebagai situs permukiman yang sedikitnya meliputi area hunian, pertanian, dan pemujaan.

Area pemujaan memang paling menonjol, yaitu meliputi bangunan-bangunan berbahan batu seperti candi, batur-batur, dan petirtaan. Area hunian ditandai dengan ditemukannya sisa bangunan kayu, sisa peralatan keseharian seperti barang-barang berbahan tembikar, keramik, logam, dan batu. Area pertanian diindikasikan oleh temuan-temuan berupa sebaran yoni penanda pertanian di bagian atas situs, peralatan pertanian berbahan logam, serta sisa padi dan biji-bijian (Riyanto, 2016: 51). Aspek temporal merupakan salah satu aspek yang menarik untuk secara khusus dicermati justru karena dalam hal ini berkaitan dengan rentang kronologi situs yang panjang dan di sisi lain area pemujaan berlatar belakang agama Hindu tampak menonjol sehingga dengan mudah dikaitkan dengan kerajaan Matarām Kuno. Hasil penentuan umur melalui analisis carbon 14 berdasarkan sampel arang bambu, kayu, dan ijuk yang dicuplik dari beberapa lokasi 
menghasilkan umur kalender Masehi 587, 742, 846, 913, dan 971 (Riyanto, 2014b: 101; Riyanto, 2015: 47).

Unsur-unsur pra-Hindu, selain ditunjukkan oleh hasil dating juga terlihat dari formasi area pemujaannya. Berbeda dengan situs candi semasa yang konsentris, area pemujaan di situs Liangan bentuknya berundak-teras. Hingga penelitian tahun 2016 ada empat teras, dapat disebut juga sebagai halaman, yang sudah ditemukan. Gejala adanya unsur pra-Hindu yang lain adalah dominasi struktur berbahan boulder dan arca "tipe polinesia" yang ditemukan tahun 2009 (Tim Penelitian, 2016: 89). Kerangka kronologis yang panjang dan berkesinambungan itu diperkuat oleh hasil penentuan umur terbaru, tahun 2016, yang menghasilkan angka kalender Masehi 181, 234, 921, dan 1061. Dengan demikian kisaran abad II - XI Masehi cocok dengan hipotesis dan kerangka kronologis hasil penelitian sebelumnya, yaitu sejak pra-Hindu hingga kejayaan Matarām Kuno. Namun demikian, fenomena Hindu sangat jelas terilhat di situs Liangan, sehingga sulit untuk dibantah pengaruh peradaban Matarām Kuno di dalam rentang panjang kronologi situs Liangan.

Boechari menyatakan bahwa nama Matarām muncul pertama kali sebagai kerajaan pada tahun $717 \mathrm{M}$ pada masa pemerintahan raja Sañjaya yang bergelar Rakai Matarām, sampai pemerintahan Dharmawangsa Tguh meskipun berkedudukan di Jawa Timur (Boechari, 2012a: 184). Pertanyaannya kemudian adalah, bagaimana gambaran situs Liangan di dalam perkembangan dan dinamika sejarah masa Matarām Kuno ? Berkenaan dengan hal itu, makalah ini ditulis dengan tujuan untuk mengulas kerangka sejarah pra-Matarām hingga masa Matarām Kuno yang berkaitan dengan situs Liangan.

Berdasarkan permasalahan dan tujuan, rujukan penting dalam hal ini setidaknya meliputi bahanbahan sekunder berupa kepustakaan yang secara khusus berkaitan kerangka sejarah masa Matarām Kuno. Rujukan tersebut dalam hal ini meliputi pustaka Sejarah Nasional Indonesia khususnya Jilid II edisi pemutakhiran (Poesponegoro dan Nugroho Notosusanto, 2011) dan Indonesia dalam Arus Sejarah (Abdullah dan A.B. Lapian, ed., 2012) khususnya Jilid II Kerajaan Hindu-Buddha. Kedua pustaka tersebut banyak menghimpun hasil-hasil kajian primer yang dinarasikan sehingga gambaran kerangka sejarah yang ditulis memiliki nilai akademis yang dapat menjadi rujukan dalam penulisan artikel ini, terutama karena ada tokoh bernama Dyah Tlodhong sebagai Rakai Layang yang kemudian menjadi raja di kerajaan Matarām pada perempat pertama abad X M. Tentu saja selain kedua pustaka tersebut, sebagai rujukan juga digunakan berbagai sumber lain yang diperlukan dalam tulisan ini.

\section{METODE}

Kerangka dasar metode kajian dalam artikel ini adalah deskriptif-analitis dengan penalaran induktif. Dalam metode ini, antara lain dilakukan analisis berbagai data arkeologi dan bahan-bahan pustaka yang berkaitan dengan situs Liangan dan kerangka sejarah Matarām Kuno secara deskriptif. Danim (2002: 41) menggambarkan bahwa penelitian deskriptif dimaksudkan untuk mendeskripsikan suatu situasi 
tertentu yang bersifat faktual secara sistematis dan akurat. Sementara itu, menurut Sumanto (1995: 77) penelitian deskriptif analitis berusaha untuk mendeskripsi dan menginterpretasi mengenai kondisi atau hubungan yang ada.

Dalam arkeologi terdapat tiga dimensi utama dalam kajianya, yaitu dimensi bentuk, dimensi waktu, dan dimensi ruang. Dalam perkembangan disiplin arkeologi, dimensi ruang (spasial) muncul belakangan dibandingkan dimensi bentuk (formal) maupun dimensi waktu (temporal) (Mundardjito, 2002: 70). Pandangan kepada ketiga dimensi tersebut sebenarnya terkait dengan perubahan tekanan perhatiannya terutama dalam hal keruangan, yaitu dari artifact oriented, kemudian site oriented, dan akhirnya region oriented. Istilah ruang dalam kajian ini mengacu pada aspek keletakan, lokasi, atau tempat ditemukannya benda arkeologi dan situs di permukaan bumi. Dalam wacana arkeologi, hal ini dikenal sebagai konsep in situ (Mundardjito, 2002: 71).

Situs Liangan secara
keruangan berada di antara sejumlah situs masa Matarām Kuno, bahkan beberapa di antaranya dalam wilayah kecamatan yang sama (Riyanto, 2014b: 54-57). Sebagai situs yang sudah diteliti sejak 2009 dan hasilnya sudah dipublikasikan dalam bentuk terbitan maupun seminar, maka bahanbahan sekunder menjadi rujukan dalam kajian ini. Berkaitan dengan hal itu data yang sifatnya sekunder dikumpulkan dengan cara menelaah sumber-sumber pustaka yang berkaitan dengan topik kajian. Demikian pula dengan analisisnya, merujuk kajian proses masuknya anasir budaya India ke Indonesia serta masa Matarām Kuno yang dikaitkan dengan data arkeologi. Dengan demikian nantinya dapat dijelaskan kedudukan situs Liangan dalam salah satu fase dalam rentang kronologis, yaitu fase Matarām Kuno dan masa sebelumnya hingga persentuhan awal dengan budaya India. Hal ini penting artinya karena Matarām Kuno tidak muncul tiba-tiba tetapi ada proses yang mendahului, dan gejala yang demikian juga terlihat di situs Liangan, yaitu ditemukannya unsur-unsur praHindu.

\section{HASIL PENELITIAN}

\section{Kronologi Situs Liangan}

Gambaran kronologis situs Liangan pada awalnya didasarkan pada hasil penelitian penjajagan tahun 2010 yaitu antara abad IX dan $X$ Masehi. Hal ini didasarkan pada dua data yaitu 1) profil klasik Jawa Tengah pada bagian kaki candi berbentuk pelipit persegi, pelipit setengah lingkaran, dan pelipit sisi genta, abad VIII-IX M; 2) hasil analisis pecahan keramik yang menunjuk pada masa Dinasti Tang, abad IX M. Pada penelitian 2011 dilakukan analisis karbon 14 atas sampel arang bambu dan menghasilkan angka 1060 BP $(1950) \pm 110$. Angka tersebut adalah umur arang bambu hasil perhitungan laboratorium (radiocarbon age) dan setelah dikalibrasi menghasilkan umur kalender (calendar age) 971 Masehi (Riyanto, 2013: 775; Riyanto, 2014b: 58-59). Berdasarkan hal itu, hingga tahun 2011 situs Liangan secara tegas dihubungkan dengan kerajaan Matarām Kuno, karena kecocokan pertanggalan.

Tahun 2013 penentuan umur situs Liangan kembali dilakukan sebagai bagian dari penelitian, dengan mencuplik sampel organik, 
kayu dan bambu, di empat lokasi ekskavasi. Hasil analisis karbon 14 oleh Badan Tenaga Nuklir Nasional menghasilkan angka kalender Masehi 587, 742, 846, dan 913. Hasil ini selain menegaskan adanya fase kronologis situs Liangan yang sejaman dengan kerajaan Matarām Kuno juga mengindikasikan durasi situs yang lebih panjang, setidaknya sejak abad VI Masehi (Riyanto, 2015: 47).

Pada penelitian 2016 penentuan umur melalui analisis karbon 14 dilakukan lagi dan jika diurutkan mulai dari yang paling tua, maka diperoleh gambaran kronologis yang semakin lengkap, sebagai berikut.

a) 1113 Sebelum Masehi \pm 60 atau abad XII SM, dari sampel tanah di kotak S50B10 blok LT1603

b) 23 Sebelum Masehi \pm 28 atau abad I SM, dari sampel tanah di kotak U11T29 blok LT1602

c) 181 Masehi \pm 34 atau abad II $M$, dari sampel tanah di kotak S24B2 blok LT1501

d) 234 Masehi \pm 50 atau abad III M, dari sampel arang kayu di kotak U15T35 blok LT1601

e) 921 Masehi \pm 27 atau abad $X$ $M$, dari sampel arang bambu di kotak S49B10 blok LT1603

f) 1061 Masehi \pm 38 atau abad XI $M$, dari sampel bambu kayu di kotak U345T28 blok LT1601 (Tim Penelitian, 2016: 88-89).

Kisaran abad II - XI Masehi cocok dengan hipotesis dan kerangka kronologis hasil penelitian sebelumnya. Akan tetapi sangat mengejutkan dengan adanya beberapa hasil yang menunjuk pada kronologi periode yang "terlalu tua", yaitu 1113 SM. Meskipun menggembirakan dan cocok dengan kisaran masa keberadaan situs Liangan secara umum, namun kronologi SM harus didalami, bukan hanya dengan pembuktian berdasarkan data budaya tetapi juga dengan gambaran dinamika periodeperiode tersebut beserta benang merahnya hingga periode Matarām Kuno.

\section{Pengaruh Budaya India di Indonesia}

Teknologi pelayaran dan perdagangan rupanya menjadi faktor penentu dalam kontak budaya antara Nusantara dan India, setidaknya sejak awal Masehi. Oleh karena itu wilayah pesisir merupakan area geografis yang strategis dalam kontak tersebut sebagai "pintu masuk", sebelum akhirnya berkembang menuju pedalaman. Hal ini berarti bahwa pada masa itu permukiman di beberapa pesisir Nusantara sudah berkembang dan mandiri. Dua situs di Bali memberikan pengetahuan tentang hal itu. Pertama, di situs Sembiran yang memperlihatkan adanya permukiman yang mapan sejak awal Masehi dan selanjutnya berkembang ke daerah pedalaman secara bertahap. Ke-dua, situs Gilimanuk sebagai permukiman yang telah memiliki pranata sosial, jauh sebelum terbentuknya kerajaan awal. Gambaran serupa, yaitu hunian menetap dengan didukung oleh pranata sosial di Jawa Tengah tercermin dari hasil penelitian arkeologi di situs Plawangan. Hasil penelitian arkeologi menunjukkan bahwa sistem penguburan di Plawangan mencerminkan adanya stratifikasi sosial pada masa itu (Poseponegoro dan Nugroho Notosusanto, 2011: 2). Selain itu, hubungan dagang dalam skala regional bahkan dapat dibuktikan 
dengan data arkeologi yang ditemukan di Buni (Jawa Barat), Sembiran (Bali), dan Karangagung (Sumatra Selatan) (Soeroso, 2006: 123). George Coedes tegas menyatakan bahwa orang-orang India telah berhadapan dengan masyarakat-masyarakat yang telah terorganisir dan berperadaban, bukan dengan orang primitif yang tidak beradab (Coedes, 2010: 35).

George Coedes kemudian menggambarkan secara hipotetis proses bagaimana para pedagang yang mencari rempah-rempah dan petualang yang mencari emas akhirnya membentuk masyarakat yang cukup homogen, terorganisir, hingga melahirkan kerjaan-kerajaan Hindu-Buddha di Indonesia. Rangkuman tersebut adalah sebagai berikut:

a) Dua atau tiga kapal dari India berlayar bersamaan dan mencapai Pulau Jawa

b) Para pendatang baru itu kemudian menjalin hubungan dengan para pemimpin setempat, membuat mereka senang dengan memberi berbagai hadiah, serta mengobati yang sakit dengan jimat

c) Pendatang harus kaya atau yang dianggap kaya, tabib, dan tukang sihir; untuk hal ini orang India paling mahir berperilaku demikian, atau bahkan mereka menyatakan diri sebagai keturunan raja untuk memberi kesan baik kepada tuan rumah

d) Para pendatang belajar bahasa setempat yang sangat berbeda dengan bahasa mereka agar dapat diterima dan diakui menjadi warga

e) Dengan menjadi warga, mereka selanjutnya mengawini anak pemimpin sebagai jalan untuk dapat memberi pengaruh peradaban dan agama pada masyarakat setempat melalui sang istri

f) Putri pemimpin yang sudah dipengaruhi oleh suaminya akan menegaskan bahwa pemikiran dan kepercayaan baru memiliki keunggulan, sehingga kemudian diserap oleh masyarakat setempat dengan menggunakan bahasa India

g) Istilah-istilah dari India yang baru dikenal itu tidak ada yang sepadan dengan bahasa Jawa sehingga dipakai apa adanya (Coedes, 2010: 50-51)

Selain bahasa dan aksara, teknologi pertanian menjadi salah satu unsur yang penting dalam perkembangan kebudayaan dan peradaban hingga nantinya terbentuk institusi kerajaan dengan gaya India. Denys Lombard tegas mengatakan ideologi baru Hindu dan Buddha, yang menurutnya lebih rukun di Jawa dibandingkan dengan di India, memiliki andil besar dalam proses penggabungan wilayahwilayah dan munculnya konsep kerajaan (Lombard, 1996: 16). Paling tidak di Jawa, sejak masa prasejarah yang mendahului masa Hindu-Buddha, telah dikenal sistem administrasi kemasyarakatan dalam dua tingkatan, yaitu setingkat desa atau dusun dan di atasnya semacam federasi antardesa (Sedyawati dkk., 2012b: 23).

Awal terbentuknya kerajaankerajaan atau dinasti baru di Jawa dijelaskan oleh George Coedes sebagai gejala umum di Asia Tenggara. Menurutnya kerajaan bergaya India didirikan dengan cara mengumpulkan beberapa kelompok masyarakat di bawah kewibawaan seorang pemimpin tunggal bangsa 
India atau pribumi yang telah menerima peradaban India. Kelompok-kelompok itu memiliki jin pelindung atau dewa tanah (Coedes, 2010: 56).

Dalam waktu yang bersamaan dilakukan pemujaan di atas gunung, alami atau buatan, terhadap dewa India yang erat hubungannya dengan tokoh raja atau yang melambangkan kesatuan kerajaan. Dengan begitu, maka pemujaan terhadap jin oleh pribumi dipertemukan dengan ideologi India tentang kerajaan, sedangkan kepada masyarakat yang dikumpulkan di bawah seorang raja tunggal diberikan sosok dewa secara "nasional". Dengan cara begitu bangsa India berhasil mengasimilasi kepercayaankepercayaan dan pemujaan asing sehingga kedua unsur saling bereaksi (Coedes, 2010: 56).

\section{Kerangka Sejarah Matarām Kuno}

Kebiasaan orang India
menulis buku-buku pedoman
(śāstra) mengenai hukum
(dharmaśāstra), politik (arthaśāstra),
dan pencarian kenikmatan
(kāmaśāstra) memuluskan proses peresapan anasir budaya India oleh bangsa Indonesia. Bahkan disebutkan bahwa orang India akhirnya dianggap "tanpa peran" karena orang Indonesia sendiri yang memperoleh keseluruhan kebudayaan India melalui buku-buku pedoman tersebut (Coedes, 2010: 55-56). Perlu diingat bahwa munculnya pemakaian tulisan tidak harus berarti ipso facto bahwa telah lahir masyarakat yang baru karena masyarakat yang terungkap pada prasasti-prasasti pertama pada saat tertentu berkembang lamban (Lombard, 1996: 16).
Meskipun pada awalnya prasasti ditulis menggunakan huruf Pallawa dan bahasa Sansekerta, namun dalam perjalanan selajutnya juga digunakan bahasa-bahasa yang nantinya menjadi cikal-bakal bahasa yang digunakan di beberapa daerah di Inonesia. Boechari pernah mencatat koleksi prasasti dalam bentuk abklats, atau cetakan kertas, yang berasal dari berbagai daerah di Indonesia dalam jumlah besar, sekitar tiga ribu. Abklats atau duplikat berbahan kertas dari prasasti berbahan batu dan logam tersebut ditulis dalam bahasa Melayu Kuno, Sunda Kuno, Jawa Kuno, dan Bali Kuno; selain bahasa "asing" Sansekerta, Arab, dan Tamil (Boechari, 2012b: 4).

Di Jawa Tengah, prasastiprasasti pertama dari awal abad VIII M mencerminkan adanya persaingan antara para penguasa yang telah berhasil mempersatukan dan menguasai sejumlah wanua atau komunitas desa. Mereka disebut raka atau rakryan yang pada akhirnya menjadi "atasan" para rama yang menjadi pembesar di tingkat wanua. Federasi regional beberapa wanua itu selanjutnya disebut watak yang namanya diberikan kepada para raka, seperti rakai Pikatan, sebagai contoh, berarti penguasa dari Pikatan. Mereka mulai banyak membangun bangunan-bangunan suci dalam usahanya meningkatkan prestise sebagai penguasa (Lombard, 1996: 14).

Salah satu fase sejarah yang banyak diungkap melalui sumber prasasti di Jawa adalah masa kerajaan Matarām Kuno. Kerajaan Matarām (bhūmi Matarām) adalah kerajaan kuno yang berpusat di Jawa Tengah. Pemerintahan kerajaan ini berlangsung dari abad VIII - X Masehi, tepatnya sejak berkuasanya Rakai Matarām Sań 
Ratu Sañjaya pada tahun 717 Masehi. Nama Matarām memang baru dikenal pada waktu itu, namun tidak berarti kerajaan ini muncul tibatiba karena sebelumnya kerajaan di Jawa Tengah hanya diketahui melalui berita Cina. Menurut sumber itu, nama kerajaan di Jawa Tengah bernama Shepo yang setidaknya sudah ada sejak tahun 420 Masehi, dan kerajaan Ho-ling yang setidaknya sudah berkuasa pada tahun 618 Masehi. Abad IX, berita Cina kembali menyebut kerajaan itu dengan nama Shepo lagi (Boechari, 2012c: 198).
Prasasti Mantyasih (907 M) dan prasasti Wanua Tengah III (908 M) yang dikeluarkan oleh raja Balitung hingga kini menjadi sumber paling penting dalam merekonstruksi historiografi Matarām Kuno, setidaknya sejak pemerintahan Sañjaya (abad VIII M) hingga Balitung (abad X Masehi). Garis besar sejarah kerajaan Matarām Kuno berdasarkan prasasti Mantyasih dan prasasti Wanua Tengah III menurut Kusen adalah sebagai berikut.

Tabel 1. Daftar Raja Matarām Kuno Menurut Prasasti Mantyasih dan Prasasti Wanua Tengah III

\begin{tabular}{|c|c|}
\hline Prasasti Mantyasih 907 M & Prasasti Wanua Tengah III 908 M \\
\hline Rakai Matarām Sang Ratu Sanjaya & Rahyangta ri Mdang \\
\hline Sri Maharaja Rakai Panangkaran & $\begin{array}{c}\text { Rake Panangkaran } \\
\text { (7 Oktober } 746-1 \text { April 784) }\end{array}$ \\
\hline Sri Maharaja Rakai Panunggalan & $\begin{array}{c}\text { Rake Panaraban } \\
\text { (1 April } 784-28 \text { Maret } 803\end{array}$ \\
\hline Sri Maharaja Rakai Warak & $\begin{array}{c}\text { Rake Warak Dyah Manara } \\
\text { (28 Maret } 803 \text { - } 5 \text { Agustu } 827)\end{array}$ \\
\hline- & $\begin{array}{c}\text { Dyah Gula } \\
\text { (5 Agustus } 827-24 \text { Januari } 828)\end{array}$ \\
\hline Sri Maharaja Rakai Garung & $\begin{array}{c}\text { Rake Garung } \\
\text { (24 Januari } 828-22 \text { Februari 847) }\end{array}$ \\
\hline Sri Maharaja Rakai Pikatan & $\begin{array}{c}\text { Rake Pikatan Dyah Saladu } \\
22 \text { Ferbruari } 847 \text { - } 27 \text { Mei 855) }\end{array}$ \\
\hline Sri Maharaja Rakai Kayuwangi & $\begin{array}{c}\text { Rake Kayuwangi Dyah Lokapala } \\
\text { (27 Mei } 855 \text { - } 5 \text { Ferbruari 885) }\end{array}$ \\
\hline- & $\begin{array}{c}\text { Dyah Tagwas } \\
\text { (5 Februari } 885-27 \text { September 885) }\end{array}$ \\
\hline- & $\begin{array}{l}\text { Rake Panumwangan Dyah Dewendra } \\
\text { (27 September } 885-27 \text { Januari } 887 \text { ) }\end{array}$ \\
\hline- & $\begin{array}{c}\text { Rake Gurunwangi Dyah Bhadra } \\
\text { (27 Januari } 887 \text { - } 24 \text { Februari } 887 \text { ) }\end{array}$ \\
\hline Sri Maharaja Rakai Watuhumalang & $\begin{array}{l}\text { Rake Wungkalhumalang Dyah Jbang } \\
\text { (27 November } 894 \text { - } 23 \text { Mei 898) }\end{array}$ \\
\hline $\begin{array}{c}\text { Sri Maharaja Rakai Watukura Dyah } \\
\text { Balitung }\end{array}$ & $\begin{array}{l}\text { Rake Watukura Dyah Balitung } \\
\text { (23 Mei } 898 \text { - } 1 \text { Oktober 908) }\end{array}$ \\
\hline
\end{tabular}

Sumber: Kusen, 1994, halaman 93 
Perbedaan daftar nama raja yang tertera dalam prasasti Mantyasih dan prasasti Wanua Tengah III disebabkan oleh perbedaan yang melatari penerbitan keduanya. Prasasti Mantyasih diterbitkan dalam rangka melegitimasi diri Balitung sebagai raja yang sah memerintah kerajaan. Oleh karena itu ia hanya mencantumkan raja yang berdaulat penuh atas kerajaan. Empat nama raja tidak dimasukkan oleh Balitung dalam daftar di prasasti Mantyasih karena dianggap tidak berdaulat penuh, hal ini tampak dari masa pemerintahan yang sangat singkat karena digulingkan. Sementara itu, prasasti Wanua Tengah III diterbitkan berkenaan dengan perubahan status sawah di Wanua Tengah sehingga dianggap perlu memasukkan nama-nama raja yang ada sangkut-pautnya dengan perubahan status tersebut. Mengapa nama Sañjaya tidak dimasukkan ? Hal ini karena riwayat status sawah di Wanua Tengah baru dimulai sejak Rakai Panangkaran (Kusen, 1994: 90).

Sayang sekali prasasti yang diharapkan dapat menjembatani fase sebelum Sañjaya dengan dimulainya masa Matarām Kuno, dengan Sañjaya sebagai rajanya, belum ditemukan hingga kini. Selain untuk melukiskan gambaran proses kontinuitas kedua fase secara lembut, jadi tidak terkesan Matarām muncul tiba-tiba, prasasti yang sangat diharapkan itu juga dapat menjadi kunci untuk menelusuri para leluhur raja-raja Matarām lebih jauh ke belakang. Di Jawa Tengah terdapat prasasti dari pertengahan abad VII M, yaitu prasasti Tuk Mas dari pedalaman Magelang dan prasasti Sojomerto dari pesisir utara Batang. Kedua prasasti ditulis dengan aksara Pallawa yang lazim digunakan di India selatan, tetapi dalam bahasa yang berbeda, prasasti Tuk Mas berbahasa Sansekerta sedangkan prasasti Sojomerto berbahasa Melayu Kuno.

Keberadaan prasasti Tuk Mas setidaknya menunjukkan bahwa anasir India memang sudah lama masuk dan cukup mapan di Jawa Tengah, karena kontak pertama tentu saja di pesisir. Hal ini sekaligus juga menggambarkan dinamika perdagangan dengan India, dan tentunya Cina, yang sudah mengenal dengan sangat baik potensi komoditi di pedalaman Jawa. Sementara itu prasasti Sojomerto menggambarkan aspek yang lebih luas, bahkan secara politik, karena menyebut nama tokoh penting yaitu Dapunta Selendra. Disebutkan dalam prasasti bahwa Dapunta Selendra adalah anak dari ayah bernama Santanu dan ibu bernama Badrawati, sedangkan istrinya bernama Sampula (Sedyawati dkk., 2012a: 173). Selain nama Dapunta Selendra yang nantinya dikaitkan dengan wangsa Sailendra, penggunaan bahasa Melayu Kuno juga dihubungkan dengan kerajaan Sriwijaya di Sumatera.

\section{Wangsa}

Sailendra selanjutnya menjadi penguasa kerajaan Matarām, mulai dari Sañjaya hingga keturunannya. Ada catatan menarik yang berasal dari berita Cina yaitu penobatan Ratu Hsimo pada tahun $674 \mathrm{M}$ dari kerajaan Ho-ling. Disebutkan bahwa Ratu Hsimo adalah leluhur raja Sañjaya. Lebih menarik lagi dengan disebutnya kerajaan Tolomo yang diserang oleh Sriwijaya pada tahun 686 M. Jika Tolomo adalah Taruma, maka waktu itu kerajaan Taruma di Jawa Barat masih berdiri (Sedyawati dkk., 2012a: 179). Artinya, pada pertengahan abad VII ada tiga kerajaan besar di Nusantara yaitu 
Sriwijaya di Sumatera bagian selatan, Taruma di Jawa bagian barat, dan Ho-ling di Jawa bagian tengah.

Ho-ling dengan Ratu Hsimo yang naik tahta pada $674 \mathrm{M}$ merupakan cikal-bakal kerajaan Matarām karena Ratu Hsimo adalah leluhur Sañjaya, raja pertama Matarām. Dalam gambaran itu barangkali ada mata rantai yang putus antara Ratu Hsimo dengan Sañjaya, yaitu raja Sanna yang disebut dalam prasasti Canggal. Prasasti ini memberitakan bahwa raja Sañjaya pada tanggal 6 Oktober 732 mendirikan lingga di puncak bukit, serta menyebut kekayaan alam Pulau Jawa antara lain berupa padi (serealia) dan emas (Coedes, 2010: 132; Poesponegoro dan Nugroho Notosusanto, 2011: 129). Diberitakan juga bahwa ibunda Sañjaya, yaitu Sannaha adalah saudara perempuan raja Ho-ling, Sanna, yang meninggal akibat serangan musuh serta kerajaannya dihancurkan. Sanna kemudian digantikan oleh Sañjaya yang dinobatkan pada tahun $717 \mathrm{M}$ di Medang yang diduga terletak di Poh Pitu. Setelah berhasil menaklukkan raja-raja kecil di sekitarnya dan membangun kembali kerajaannya ia kemudian mendirikan lingga di bukit yang didokumentasikan melalui prasasti Canggal (Sedyawati dkk., 2012a: 180-181). Sanna, Sannaha, dan Sañjaya mungkin sekali memang pewaris Dapunta Selendra, oleh karena itu mereka juga bagian dari wangsa Sailendra. Sebagaimana diberitakan dalam prasasti Mantyasih (907 M), Sañjaya merupakan raja pertama yang bertakhta di Mědang. Selanjutnya ia disusul oleh Rakai Panangkaran yang jelas menyebut dirinya sebagai "Permata wangsa Sailendra". Gambaran ini mungkin tidak lengkap karena ada kemungkinan antara Dapunta Selendra dan Ratu Hsimo, atau antara Ratu Hsimo dengan Sanna masih ada tokoh raja lagi yang belum diketahui (Poesponegoro dan Nugroho Notosusanto, 2011: 131). Urutan raja-raja Matarām berikutnya, berdasarkan prasasti Mantyasih dan prasasti Wanua Tengah III, dari Panangkaran (746 - $784 \mathrm{M})$ hingga Balitung (898 - 908 M) dapat disimak pada Tabel.

Gambaran urutan raja-raja Matarām menjadi rumit dengan dimasukannya Samaratungga oleh Coedes sebagai raja di Jawa di antara masa pemerintahan Rakai Warak. la diidentifikasi sebagai Samarāgrawīra, keturunan Sailendra dari Jawa yang disebut dalam prasasti Nālandā. Kerumitan sedikit terurai pada masa pemerintahan Rakai Pikatan yang bermusuhan dengan Bālaputra, "anak bungsu" Samaratungga hasil perkawinannya dengan putri Tāra dari Sriwijaya yang beragama Buddha. Setelah kalah dari Rakai Pikatan, Bālaputra pulang ke negeri ibunya di Sumatera. Dalam konteks itu, Pikatan juga mengawini saudara perempuan Bālaputra, bernama Pramodāwarddhani sehingga dalam hubungan keluarga Pikatan adalah menantu Samaratungga (Coedes, 2010: 156).

Di antara Kayuwangi dan Sindok sebenarnya ada tokoh yang menonjol, yaitu Rakai Watukura Dyah Balitung. Manurut prasasti Wanua Tengah III, ia memerintah dari tahun 898 -908 M, waktu yang tidak singkat dalam masa pemerintahan raja di Jawa. Selama pemerintahannya ia berhasil meluaskan kekuasaannya hingga Jawa bagian timur dengan menaklukkan kerajaan Kañjuruhan yang sejak pertengahan abad VIII M 
berpusat di sekitar Malang. Kañjuruhan selanjutnya menjadi bagian dari Matarām yang dikuasai oleh seorang rakai, yaitu Rakarayān Kanuruhan. Selain itu, tahun $907 \mathrm{M}$ Balitung mengeluarkan prasasti Rukam untuk memperingati perintah raja yang menetapan Desa Rukam menjadi sima karena desa itu hancur oleh letusan gunung (Poesponegoro dan Nugroho Notosusanto, 2011: 171-172).

Setelah masa Balitung, situasi politik semakin tidak menentu akibat perebutan kekuasaan, bahkan di kalangan keluarga dan kerabat kerajaan. Balitung yang berasal dari Watukura dianggap tidak memiliki hak atas takhta kerajaan, ia menjadi raja karena perkawinannya dengan putri raja sebelumnya, dan bukan keturunan langsung dari Pikatan. Daksa atau Śri Dakșottama Bāhubajra Pratipakșakșaya yang menjabat sebagai putra mahkota (Rakryān Mahamantri I Hino) bukan anak Balitung tetapi kemungkinan iparnya. Daksa dan Rakai Gurunwangi, keduanya kerabat Rakai Pikatan, bersekongkol untuk merebut kembali takhta kerajaan dari Balitung dan berhasil naik takhta sejak 910/911 M selama 8 tahun. la mengangkat seorang putra mahkota, yaitu Rakai Layang Dyah Tlodhong yang ternyata bukan pejabat eselon pertama. Selanjutnya Rakai Layang menggantikan Daksa sebagai raja Matarām, kemungkinan sekitar 918 atau $919 \mathrm{M}$. Pemerintahan Rakai Layang antara lain ditandai dengan pembangunan bendungan di Sungai Hariñjing pada 19 September 921 M, sebelum akhirnya digantikan oleh Rakai Sumba Dyah Wawa pada tanggal 14 Februari 928 M. Dyah Wawa bukan anak Tlodhong dan sebenarnya tidak berhak atas takhta kerajaan Matarām. Pemerintahannya sangat singkat bahkan berhenti mendadak, dan berita berikutnya adalah raja Sindok yang memindahkan kerajaannya ke bagian timur Jawa. Pu Sindok membangun pusat kerajaannya di Tamwlang sekaligus membangun wangsa yang baru, yaitu Iśāna, meskipun sebenarnya masih anggota wangsa Sailendra (Poesponegoro dan Nugroho Notosusanto, 2011: 173-184).

\section{DISKUSI DAN PEMBAHASAN}

Angka kalender termuda berdasarkan hasil analisis karbon 14 adalah abad XI M, tepatnya 1061 Masehi \pm 38 sangat menarik terutama jika dikaitkan dengan perpindahan kerajaan Matarām ke timur. Sebenarnya hal ini tidak sulit untuk dijelaskan karena perpindahan tersebut tidak berarti memindahkan seluruh isi kerajaan hingga peradaban di Jawa Tengah lenyap. Harus digarisbawahi bahwa Sindok memindahkan pusat kerajaannya ke tempat yang sudah dibangun peradabannya oleh raja-raja sebelumnya ketika masih berkuasa di Jawa Tengah. Di sisi lain dapat dipastikan bahwa sebagian tempattempat peradaban Matarām Kuno di Jawa Tengah masih terus tumbuh dan tidak habis sama sekali. Hal ini antara lain dibuktikan oleh prasasti yang ditulis pada jaman Kadiri tetapi ditemukan di Jawa Tengah, yaitu prasasti bertarikh $1100 \mathrm{M}$ yang ditemukan di Desa Pojok, Semarang, dan prasasti berangka tahun $1210 \mathrm{M}$ yang ditemukan di kawasan Dieng (Sedyawati, dkk., 2012a: 197). Bukan hal yang mustahil Liangan menjadi salah satu situs yang memiliki data arkeologi untuk menerangkan tentang apa yang terjadi di Jawa bagian tengah setelah Matarām berpindah ke bagian timur. 
Dalam kerangka sejarah mengenai masuknya pengaruh India di Indonesia hingga tumbuhnya kerajaan Matarām Kuno, dinamika politik beriringan dengan penciptaan karya-karya seni yang ditopang oleh teknologi arsitektur, serta melonjaknya kehidupan ekonomi melalui perdagangan yang didukung oleh teknologi pelayaran. Teknologi pertanian juga tidak kalah pentingnya, bahkan bersama hasil tambang berupa emas, padi menjadi komoditi dagang seperti diberitakan dalam prasasti Canggal (732 M). Liangan kuno bukan tidak mungkin menjadi salah satu pendukung ekonomi kerajaan, terbukti dengan ditemukannya fitur lahan pertanian, peralatan pertanian, bahkan hasil pertaniannya, khususnya padi.

Tidak ada kolonisasi dan "indianisasi" di Liangan kuno, kecuali hanya seleksi dan "mutasi" karena penduduk Liangan kuno sudah teratur jauh sebelumnya sehingga unsur-unsur lokal dapat beriringan dengan unsur India. Dominasi struktur boulder dan tata ruang berundak-teras adalah unsur lokal yang tampak secara fisik sekaligus menandakan masih kuatnya alam pemikiran pra-Hindu pada masyarakat. Kehadiran barangbarang keramik produk Dinasti Tang dalam jumlah besar bukan hanya cermin kekayaan masyarakat secara ekonomi tetapi juga menunjukkan bahwa Liangan kuno memiliki kedudukan penting dalam konteks kerajaan Matarām Kuno, sehingga barang-barang dari Tiongkok hadir di sana.

masa Matarām Kuno sudah diberitakan melalui beberapa prasasti. Prasasti Gondosuli II atau Prasasti Puhawang Glis (827 M) yang berbahasa Melayu Kuno menyebut kata dan puhawan (nahkoda), sedangkan yang ditulis dalam bahasa Jawa Kuno adalah Prasasti Tulang Air $(850 \mathrm{M})$ yang menyebut marhyan iñ prasāda kabanyagān (marhyan dalam bangunan suci kelompok banyagā). Ada empat istilah bagi pedagang yang terdapat dalam prasasti, yaitu abakul atau pedagang eceran; adagan mungkin semacam grosir; hiliran, yakni sebutan untuk pedagang yang hanya berjualan di hilir sungai-sungai besar; dan banyagā, yakni pedagang besar yang melakukan perdagangan antarpulau atau pedagang yang sudah bertaraf internasional (Suhadi dan Titi Surti Nastiti, 2012: 107). Dengan demikian maka Liangan kuno telah tumbuh menjadi bagian dari peradaban kerajaan Matarām Kuno, terletak di lereng Sindoro yang subur, meskipun memiliki potensi bencana yang mengancam orang-orang yang bermukim di sana. Dalam periode HinduBuddha, peradaban Liangan memang beriringan dengan tumbuh dan berkembangnya kerajaan Matarām Kuno, dan dalam waktu tersebut ada dua orang raja yang dapat dikaitkan dengan keberadaan permukiman ini. Pertama adalah Rakai Watukura Dyah Balitung berkenaan dengan dikeluarkannya prasasti Rukam, berangka tahun 907 M. Prasasti ini ditemukan pada tahun 1975 di Desa Petarangan, Kecamatan Parakan, berjarak sekitar $12 \mathrm{Km}$ di selatan atau secara georafis di bawah situs Liangan. Bagian yang sering dikaitkan dengan Liangan adalah yang menyebutkan "... wanua i rukam wanua wanua $i$ dro sanka yan hilan denin guntur ..." yang artinya "... desa Rukam yang termasuk wilayah kutagara atau negeri ageng, yang telah hancur oleh letusan gunung..." (Nastiti dkk., 1982: 23, 36). Kondisi situs Liangan 
yang terkubur material vulkanis itulah yang selalu dikaitkan dengan prasasti ini. Jika merujuk hasil analisis karbon 14 yang menunjuk angka kalender 1061 Masehi \pm 38 hal ini menjadi sulit untuk disepakati karena yang diberitakan dalam prasasti adalah kejadian sebelum tahun $907 \mathrm{M}$, sedangkan permukiman Liangan masih ada setidaknya hingga pertengahan abad XI M.

Pada waktu ditemukan, prasasti ini satu konteks dengan alat-alat upacara dari perunggu, yaitu baki berbentuk bulat yang tersusun mulai dari yang kecil sampai dengan yang besar, bokor, cepuk, entong, gantungan lampu, mangkuk-mangkuk perunggu, keramik asing, serta beberapa benda kecil lainnya (Nastiti dkk., 1982, 7). Barang-barang tersebut semuanya juga ditemukan di Liangan, hal ini membuka kemungkinan adanya keterkaitan antara prasasti Rukam dengan Liangan. Ada catatan penting dalam artikel Agni Sesaria Muchtar, yaitu koreksi atas anggapan bahwa wanua $i$ rukam adalah desa yang hilang karena terjadinya letusan gunung berapi, namun sebenarnya wanua $i$ rukam adalah desa yang menggantikan status sima dari desa lainnya yang hilang karena letusan gunung berapi (Muchtar, 2014: 160). Jika demikian maka Rukam merupakan desa yang pada tahun $907 \mathrm{M}$ mendapat anugerah sima dari Balitung untuk menggantikan status sima dari sebuah desa, bukan Liangan, yang hancur oleh letusan gunung. Gambaran ini menjadi sesuai dengan kronologi situs karena permukiman Liangan kuno masih ada setidaknya hingga pertengahan abad XI M, sebelum akhirnya juga harus terkubur oleh material letusan gunung Sindoro, tentunya terjadi setelah pertengahan abad XI M.

Desa Rukam merupakan daerah penting dalam pemerintahan Balitung, sebagaimana kutipan berikut.

"Di dalam prasasti Rukam diperingati perintah raja untuk menetapkan menjadi sima Desa Rukam yang masuk wilayah pusat kerajaan bagi Rakryān Śanjiwana Nini Haji, karena desa itu pernah hancur oleh letusan gunung. Kewajiban sima itu adalah memberi persembahan kepada bangunan suci di Limwung dan membuat sebuah kamūlān. Penghasilan pajak Desa Rukam sebanyak 5 dhārana perak dan pilih mas (?) sebanyak 5 māsa hendaknya dipersembahkan kepada bangunan suci di Limwung itu, dan penduduknya berkewajiban melakukan kerja bakti (buñcang haji) untuk pengelolaan kamulan" (Poesponegoro dan Nugroho Notosusanto, 2011: 172).

Limwung yang disebut dalam prasasti Rukam mengingatkan pada nama mesjid kuno Wali Limbung di Dusun Kauman, Desa Medari, Kecamatan Ngadirejo, sekitar $5 \mathrm{Km}$ arah timur dari situs Liangan. Di sekitar lokasi mesjid juga ditemukan batu-batu komponen bangunan candi. Menurut informasi warga, batu-batu tersebut dikumpulkan dari lokasi mesjid ketika dilakukan renovasi. Oleh karena itu, sangat mungkin di lokasi inilah tempat bangunan suci dan kamulan berada, seperti yang disebut dalam prasasti Rukam. 
Raja Matarām lainnya yang diduga terkait dengan Liangan adalah Dyah Tlodhong. Nama lengkapnya adalah Rakai Layang Dyah Tlodhong, gelarnya sebagai raka $i$ layang inilah yang dihubungkan dengan nama Liyangan (menurut ejaan warga) atau Liangan (ejaan pemerintah). Kemungkinan Daksa mengangkat Tlodhong sebagai putera mahkota setelah ia mengalahkan Balitung, sekitar tahun 908 M. Pada waktu itu Tlodhong menjadi penguasa daerah Layang yang mungkin juga lebih dikenal sebagai daerah layangan. Meskipun masih diperlukan kajian lebih mendalam secara linguistik, tetapi kata layangan dan liyangan yang sangat dekat menjadi pertimbangan untuk mengatakan bahwa liyangan adalah layang, daerah yang menjadi tempat asal Dyah Tlodhong. Jika hal ini benar, maka situs Liangan merupakan daerah watak yang salah satu penguasanya, Dyah Tlodhong, menjadi raja Matarām menggantikan $\mathrm{Pu}$ Daksa, setidaknya sejak $919 \mathrm{M}$ hingga $928 \mathrm{M}$. Hingga pertengahan abad XI permukiman Liangan kuno masih ada, tentunya yang berkuasa setelah Dyah Tlodhong menjadi raja Matarām adalah kerabat Dyah Tlodhong sendiri, dan mungkin juga bergelar Rakai Layang, yang akhirnya menjadi nama dusun dan situs Liangan sekarang.

\section{KESIMPULAN}

Corak budaya India pada karya-karya fisik peradaban Matarām Kuno dan terbentuknya institusi monarki bergaya India tidak berarti dominasi budaya India atas Indonesia. Jika "indianisasi" diartikan sebagai penyebaran kebudayaan India ke berbagai belahan dunia melalui pelayaran samudera sekitar awal Masehi, maka ketika masuk ke nusantara mereka berhadapan dengan masyarakat yang sudah beradab. Oleh karena itu corak dan gaya India dalam karya peradaban Matarām Kuno tidak sungguhsungguh dominan karena warna "asli" Nusantara selalu dapat dikenali. Hasil penelitian di situs Liangan banyak memberi gambaran tentang hal itu.

$\begin{array}{lr}\text { Unsur-unsur } & \text { pra-Hindu } \\ \text { (istilah "pra-Hindu" } & \text { khusus }\end{array}$ digunakan di situs Liangan karena tidak ada unsur Buddha di Liangan) sangat jelas terlihat pada data arkeologi yang ditemukan di Liangan. Kombinasi unsur-unsur pra-Hindu dan gaya India dapat menjadi dasar untuk menyimpulkan bahwa ada kesinambungan peradaban di Liangan, setidaknya sejak abad II - XI Masehi. Dalam hal ini memang masih diperlukan pendalaman kajian kronologis untuk menjelaskan rangkaiannya dari fase pra-Hindu, fase transisi, hingga fase kejayaan Matarām Kuno. Mengacu pada kerangka sejarah, bahkan Liangan diduga merupakan daerah asal Rakai Layang Dyah Tlodhong, raja Matarām sebelum Wawa dan Sindok. Kerangka sejarah kerajaan Matarām Kuno yang ditarik ke belakang hingga persentuhan awal dengan budaya India dengan Nusantara, Jawa khususnya, memberi penjelasan adanya kesesuaian antara kerangka sejarah tersebut dengan kronologi situs Liangan.

Dalam bagian yang lain, berdasarkan kerangka sejarah Matarām Kuno disimpulkan bahwa Liangan bukanlah wanua i rukam yang dalam prasasti Rukam (dikeluarkan oleh Balitung tahun 907 M) diberitakan hancur karena letusan gunung. Berdasarkan pembahasan, disimpulkan bahwa 
kemungkinan Liangan adalah layang yaitu daerah tingkat watak yang dikuasai oleh Rakai Layang Dyah Tlodhong. Setelah Daksa merebut takhta dari kekuasaan Balitung sekitar tahun $908 \mathrm{M}$, raka i layang inilah yang diangkat menjadi putra mahkota dan selanjutnya menjadi raja Matarām dari tahun 918 atau 919 hingga 928 M. Setelah ditinggalkan oleh Tlodhong karena menjadi raja Matarām, daerah layang kemungkinan diperintah oleh kerabat Tlodhong sendiri, dan terus ada bahkan setelah Sindok memindahkan pusat kerajaan ke Jawa Timur pada 929 M. Permukiman dan peradaban di layang akhirnya benar-benar berhenti hanya karena muntahan material letusan dahsyat gunung Sindoro; belum dapat dipastikan kejadiannya namun mestinya setelah pertengahan abad XI M.

Pertanyaan selanjutnya adalah, apa hubungan wanua $i$ rukam dengan layang? Jawabannya sebenarnya sederhana, yaitu keduanya hidup berdampingan di bawah naungan kerajaan Matarām. Wanua i rukam jelas menjadi tempat yang istimewa bagi Balitung karena desa itu ada hubungannya dengan leluhur raja, Rakryān Śanjiwana Nini Haji. Desa itu bahkan mendapat anugerah status sima untuk menggantikan status sima dari desa yang hilan denin guntur, dan warganya berkewajiban membangun kamulan serta memelihara bangunan suci di limwung. Jika limwung sama dengan limbung yang sekarang menjadi nama mesjid kuno, maka limwung dan mungkin juga wanua $i$ rukam hidup berdampingan dengan layang di lereng Sindoro dengan jarak keduanya hanya $5 \mathrm{~km}$. Berdasarkan pembahasan diketahui bahwa tingkatan keduanya berbeda, rukam adalah wanua sedangkan layang adalah watak, oleh karena itu mungkin saja wanua i rukam merupakan bagian dari federasi antarwanua di bawah rakai layang, karena kedekatan jarak keduanya dan perbedaan tingkatannya.

\section{UCAPAN TERIMA KASIH}

Penulis mengucapkan apresiasi dan terima kasih sebesarbesarnya kepada petugas perpustakaan Balai Arkeologi D.I. Yogyakarta yang dengan sabar telah melayani peminjaman buku-buku yang sangat bermanfaat dalam penulisan artikel ini. 


\section{DAFTAR PUSTAKA}

Adullah, Taufik. 2012. Indonesia Dalam Arus Sejarah, Jilid II Kerajaan HinduBuddha. A.B. Lapian (Ed.). Jakarta: PT Ichtiar Baru Van Hoeve.

Boechari. 2012a. "Kerajaan Matarām Sebagaimana Terbayang dari Data Prasasti". In Melacak Sejarah Kuno Indonesia Lewat Prasasti, 183-196. Jakarta: Penerbit Kepustakaan Populer Gramedia.

Boechari. 2012b. "Epigrafi dan Sejarah Indonesia". In Melacak Sejarah Kuno Indonesia Lewat Prasasti, 3-28. Jakarta: Penerbit Kepustakaan Populer Gramedia.

Boechari. 2012c. "Satu atau Dua Dinasti di Kerajaan Matarām Kuno?". Melacak Sejarah Kuno Indonesia Lewat Prasasti, 197-202. Jakarta: Penerbit Kepustakaan Populer Gramedia.

Coedes, George. 2010. Asia Tenggara Masa Hindu-Buddha. Jakarta: Penerbit Kepustakaan Populer Gramedia.

Danim, Sudarwan. 2002. Menjadi Peneliti Kualitatif. Bandung: Pustaka Setia.

Kusen. "Raja-raja Matarām Kuno dari Sañjaya sampai Balitung, Sebuah Rekonstruksi Berdasarkan Prasasti Wanua Tengah III". Berkala Arkeologi, Tahun XIV, Edisi Khusus (1994): 82-94.

Lombard, Denys. 1996. Nusa Jawa: Silang Budaya, Sejarah Kajian Terpadu. Jilid III: Warisan Kerajaan-kerajaan Konsentris. Jakarta: Penerbit PT Gramedia Pustaka Utama.

Muchtar, Agni S. 2014. "Wanua I Rukam, Nama Asli Situs Liyangan? (Kajian Terhadap Prasasti Rukam 907 M Sebagai Data Pendukung Penelitian Situs Liyangan)". In Liangan, Mozaik Peradaban Mataram Kuno di Lereng Sindoro, 149-163. Yogyakarta: Kepel Press.

Mundardjito. "Arkeologi Keruangan: Konsep dan Cara Kerjanya”, In Kumpulan Makalah Pertemuan IImiah Arkeologi VII, 2002, 70-75. Jakarta: Ikatan Ahli Arkeologi Indonesia.

Nastiti, Titi Surti, dkk. 1982. Tiga Prasasti Dari Masa Balitung. Jakarta: Pusat Penelitian Arkeologi Nasional, Departemen P \& K.

Poesponegoro, Marwati Djoened dan Nugroho Notosusanto, 2011. Sejarah Nasional Indonesia, Jilid II Zaman Kuno. Tim Nasional Penulisan Sejarah Indonesia (Ed.). Edisi Pemutakhiran. Cetakan ke-5. Jakarta: Balai Pustaka.

Riyanto, Sugeng. "Letusan Gunung Sindoro Mengubur Situs Mataram Kuno Liyangan". In Seminar Antarbangsa ke-2 Arkeologi, Sejarah, dan Budaya, 
2013, 767-781. Bangi: Istitut Alam dan Tamadun Melayu, Universiti Kebangsaan Malaysia.

Riyanto, Sugeng. 2014a. "Menggali Peradaban Mataram Kuno di Liangan Tahap Demi Tahap". In Liangan, Mozaik Peradaban Mataram Kuno di Lereng Sindoro, 31-115. Yogyakarta: Kepel Press.

Riyanto, Sugeng. 2014b. "Prolog, Mozaik Peradaban Liangan Kuno". In Liangan, Mozaik Peradaban Mataram Kuno di Lereng Sindoro, 1-29. Yogyakarta: Kepel Press.

Riyanto, Sugeng. "Situs Liangan: Ragam Data, Kronologi, dan Aspek Keruangan", Berkala Arkeologi, Vol. 35. No. 1 (Mei 2015): 31-50.

Riyanto, Sugeng. 2016. Liangan, Kini, Doeloe, dan Esok. Yogyakarta: Kepel Press.

Sedyawati, Edi dkk. 2012a. "Dinasti, Agama, dan Moumen". In Indonesia Dalam Arus Sejarah, Kerajaan Hindu-Buddha, 171-2013. Jakarta: PT Ichtiar Baru Van Hoeve.

Sedyawati, Edi dkk. 2012b. "Pengenalan Masa Hindu-Buddha". In Indonesia Dalam Arus Sejarah, Kerajaan Hindu-Buddha, 5-35. Jakarta: PT Ichtiar Baru Van Hoeve.

Soeroso. 2006. "Awal Pembentukan Kerajaan-kerajaan". In Permukiman di Indonesia Perspektif Arkeologi, 122-136. Jakarta: Pusat Penelitian Arkeologi Nasional.

Suhadi, Machi dan Titi Surti Nastiti. 2012. "Perdagangan dan Politik". In Indonesia Dalam Arus Sejarah, Kerajaan Hindu-Buddha, 107-169. Jakarta: PT Ichtiar Baru Van Hoeve.

Sumanto. 1995. Metodologi Penelitian Sosial dan Pendidikan. Yogyakarta: Penerbit Andi Offset.

Tim Penelitian. 2016. "Laporan Penelitian Situs Liangan, Temanggung, Jawa Tengah". Balai Arkeologi D.I. Yogyakarta. Tidak terbit. 
